\title{
CONTROL OF U.S. TRADE WITH CHINA: AN OVERVIEW
}

\author{
KAZIMIERZ GRZYBOWSKI*
}

\section{INTRODUCTION}

The political approach to foreign trade has a long history in the United States, especially in our dealings with communist countries. For example, the emergence of the Soviet regime in Russia after the 1917 Revolution was greeted in this country with misgivings and a concomitant refusal to recognize the new government. That recognition and the settlement of outstanding economic and political questions between the U.S. and Russia came only after the rise of Hitlerism upset the balance of power in Europe. Similarly, the Soviet-Nazi Alliance of August, 1939 affected American relations with Russia, as did the German attack on the Soviet Union in 1941. This article examines the development of the legal basis for foreign trade with Communist China and suggests alternative structures for future economic relations.

\section{Trade Restrictions Imposed on Communist Countries in General}

\section{A. Legislation}

In the post World War II period, the Soviet Union became the center of a system of states with communist governments which extended from Central Europe to Asia. The expansion of communism over this vast area led to the Cold War in which trade restrictions became an important instrument of policy. One important component of those restrictions, the Trading With the Enemy Act of 1917, ${ }^{1}$ antedates the Cold War, but provided a workable basis for controlling economic cooperation with the communist countries. Similarly, the Johnson Debt Default Act, enacted in 1934, which originally prohibited certain financial transactions by private persons involving foreign governments which were in default of their obligations to the United States, ${ }^{2}$ was later used as an instrument for restricting trade with the socialist countries. The most important piece of legislation specially designed to impose controls on trade

*Professor of Law, Duke University.

150 U.S.C. App. $\$ \S 1-44$ (1970). U.S. foreign trade regulations affecting China since the establishment of the communist regime in 1949 are described in a number of studies and articles in legal and professional journals; some of them are cited in subsequent footnotes. A more complete bibliography may be found in Note, Recent Changes in United States Trade Regulations Affecting the People's Republic of China: A Market Decontrolled, 13 VA. J. INT'L L. 78 (1973). See also Reghizzi, Legal Aspects of Trade With China: The Italian Experience, 9 HaRv. INT'L L.J. 85 (1968); Starr, Developing Trade With China, 13 VA. J. INT'L L.J. 13 (1973).

218 U.S.C. $\$ 955(1970)$. While its main effect was on the terms of credit, which at one time were quite general and absolute, as time went by the terms of the Johnson Act became quite diluted. See Starr, Trading With the U.S.S.R. and China, 28 Bus. LAw. 1301, 1303-04 (1973). 
with communist nations was the Export Control Act of $1949,{ }^{3}$ which was replaced twenty years later by the Export Administration Act of 1969.4 Virtually all of this legislation provided for regulatory action which gave the relevant government agency great control over U.S. trade.

\section{B. Regulatory Action}

The mechanism of trade regulation established by the Trading With the Enemy Act of 1917 continues to serve as the basis for regulations issued by the Office of Foreign Assets Control of the Department of the Treasury. These regulations prohibit any United States citizen or resident or any Americancontrolled corporation-irrespective of the country in which it is doing business-from dealing with communist countries unless properly licensed by the U.S. Government. With respect to China and Cuba, the result was once a total prohibition against exportation of any goods or unpublished technical data. This prohibition applied even to goods and data which were not of U.S. origin. In addition, purchase of commodities of Chinese origin was prohibited, even if for resale or for export to non-American markets. Bunkering or delivery of petroleum products to Chinese ships, Chinese chartered ships, or to ships which could have called at Chinese ports was also proscribed. Finally, all Chinese assets (some $\$ 71$ million) ${ }^{5}$ were blocked and frozen.

Pursuant to the Trading With the Enemy Act of 1917, the Treasury Department has also issued Transaction Control Regulations ${ }^{6}$ which authorize the scrutiny and licensing of all exports to communist countries according to both classes of goods and the country to which the delivery is to be made. The power to license such exports is shared by the Treasury and Commerce Departments; in fact, to avoid conflicts over authority, the Treasury Department automatically confirms export licenses approved by the Commerce Department. $^{7}$

The Export Control Act of 1949-administered by the Office of Export Control of the Bureau of International Commerce of the Department of Commerce-has served as a basis for the compilation of the Commodity Control List which, by an ingenious method, permits the regulatory agency to control the flow of exports in support of U.S. foreign policy. The Commodity Control List classifies, according to a code letter, each commodity requiring an export license from the Office of Export Control. Correspondingly, each country to which American exports may be directed is grouped in one of eight categories according to another classification system designated by the letters from $Q$ to $Z$. Thus, the resultant combination of two letters will indicate which commodities require a license depending upon the destination of the export. Commodities listed under category " $A$ " require an export license for all destinations, while all countries in group " $\mathrm{Z}$ "-in which China was placed at the time of its entry into the Korean War-require export licenses for all

\footnotetext{
${ }^{3}$ Act of Feb. 26, 1949, ch. 11, $\S ~ 1-12,63$ Stat. 7 (expired 1969).

450 U.S.C. App. $\$ \S 2401-13$ (1970).

S See Note, supra note 1 , at 83-84.

631 C.F.R. $\$ \S 505.01-505.60$ (1973).

7 Id. $\$ 500.533(\mathrm{a})(1)$.
} 
classes of goods. So long as China remained in class "Z," practically no exports to that country were permitted. ${ }^{8}$

\section{1969 Modifications}

In 1969, the Export Control Act expired and was superseded by the Export Administration Act, ${ }^{9}$ which reoriented the policies export controls were designed to serve. The 1949 Act was intended to prevent distribution to any nation representing a threat to U.S. national security of those commodities which would make a significant contribution to the military or economic potential of such nations. ${ }^{10}$ While the 1969 Act retained the entire mechanism of controls and regulations governing the licensing of exports, it modified significantly the overall purpose of trade restrictions, limiting the absolute prohibition of exports only to those items which would make a "significant contribution to the military potential" of the country of destination. ${ }^{11}$ In addition, the 1969 Act was no longer specifically oriented against communistdominated nations.

The Export Administration Act of 1969 was the result of the growing conviction that the 1949 Act failed to achieve its purpose. The Soviet Union and the P.R.C. had forged ahead with programs of economic and military development, while the 1949 Act merely diverted Soviet and Chinese purchases from the U.S. to other countries following a less restrictive policy. Hence, the requirement that American commodities or technological data must not contribute to the economic potential of the country of destination was eliminated. Moreover, the criterion of availability was promulgated as a basis for licensing the export of a commodity or technology to a communist country included on the Commodity Control List. Undoubtedly, an important consideration bearing on this liberalizing trend in export controls was the need to improve our balance of payments.

\section{II}

\section{Restrictions on Trade With China}

China emerged from World War II a close ally of the United States, which had supported its ambition to achieve unification, independence, and leadership in the postwar world. Not until the communist take-over in 1949 did the U.S. Government adopt any restrictive measures aimed specifically at controlling and restricting trade with China. At the same time, formulation of the Marshall Plan to assist in the European reconstruction caused the United States to adopt a policy of allocating materials in short supply to countries which participated in the Marshall Plan. Discrimination against other countries was, at that time, merely an unintended side effect, not an immediate goal of the U.S. Government. However, as the Soviet Union embarked on the policy of establishing communist regimes in Eastern Europe, the element of national

\footnotetext{
${ }^{8}$ See Note, supra note 1 , at $80-81$.

950 U.S.C. App. $\$ \S 2401-13$ (1970).

${ }^{10}$ Act of Feb. 26, 1949, ch. $11, \S \S 1-12,63$ Stat. 7 (expired 1969).

1150 U.S.C. App. § 2402 (1970).
} 
American-owned) to suspend execution of the contract since it was in violation of the U.S. Transaction Control Regulations. ${ }^{17}$ The French minority directors instituted proceedings when Fruehauf attempted to comply with the Treasury Department directive. A temporary administrator was appointed by a French court for the execution of the contract, and eventually the purposes of the U.S. policy were frustrated. The French courts clearly acted in defense of French economic interests, seeing to it that French foreign policy prevailed over that of the United States. ${ }^{18}$

As a result of this conflict, the Treasury Regulations were amended to provide that American firms in COCOM countries would no longer be subject to the requirement that they obtain a U.S. license in addition to the one issued by the host country for export of prohibited goods and technical data to China. ${ }^{19}$ On the other hand, it continues to be the position of the U.S. Government that a subsidiary or licensee residing or doing business in a non-COCOM country remains subject to U.S. licensing regulations. Nevertheless, the recent exportation of automobiles manufactured by American companies in Argentina to a communist nation suggests that U.S. jurisdiction in even non-COCOM countries may be seriously circumscribed.

\section{IV}

\section{The New Course}

On June 10, 1971, controls on a large list of nonstrategic U.S. exports to the People's Republic of China were terminated ${ }^{20}$ in accordance with the provisions of the Export Administration Act of 1969, as amended by the Equal Export Opportunity Act of 1972,21 signaling a new era in Sino-American trade relations. That move did not arrive unheralded. It was preceded by modification of restrictions on the travel of U.S. citizens to China, permission for American tourists to import Chinese goods for noncommercial purposes, ${ }^{22}$ and allowance of trade in nonstrategic goods with China by U.S. firms abroad, provided that U.S. dollars were not used in the transactions. ${ }^{23}$ In addition, nonstrategic foreign-made products incorporating American produced components and parts were authorized for sale and shipment to the P.R.C. in April, 1970, subject only to obtaining an export license in each case. ${ }^{24}$ The following August, bunkering of free world ships carrying nonstrategic goods to the P.R.C. with petroleum products of non-U.S. origin was permitted. ${ }^{25}$ Finally,

\footnotetext{
1731 C.F.R. $\S \S 505.01-505.60$ (1973).

${ }^{18}$ See also id. $\S 500.29$, which extends U.S. jurisdiction to corporations and other entities abroad owned and controlled by any citizen or resident of the United States or any person actually present within the U.S.

1937 Fed. Reg. 3511,3520 (1972).

${ }^{20}$ For a summary of those lists, see 64 Dep't State Buli. 815 (1971). A more detailed listing may be found in 36 Fed. Reg. 11,808 (1971).

${ }^{21}$ Act of Aug. 29, 1972, §§ 101-210, 86 Stat. 644.

2234 Fed. Reg. 12,179 (1969).

${ }^{23}$ Id. at 12,189 .

${ }^{24}$ U.S. Dep't of Commerce, Export Control Bull. (Office of Export Control Pub. No. $16,1970)$.

${ }^{25}$ Letter from U.S. Dep't of Treasury to interested firms, Aug. 26, 1970.
} 
security became increasingly more dominant in the allocation of materials.

The communist take-over in China in October, 1949, precipitated a prohibition against exports of certain goods to China. The forbidden list was expanded the following year with the outbreak of the Korean War and China's intervention. A total prohibition of exports to what was now the People's Republic of China was ordered in December, $1950,{ }^{12}$ including the revocation of already issued export licenses. In addition, American planes and ships were forbidden to land at Chinese airfields or call at Chinese ports; assets of Chinese nationals residing in the United States were blocked (in response to the confiscation of all American property in China); imports from China to the U.S. were prohibited; parcel post shipments from China were barred; and U.S. passports began to list China among the countries where travel for American citizens was not authorized. Finally, the Foreign Assets Control Regulations blocked assets in the United States which were owned by residents of China. ${ }^{13}$

\section{III}

\section{International Coordinating Committee on Strategic Trade With Communist Countries (COCOM)}

In 1949, informal consultations were initiated between the U.S. Government and its allies to achieve economic cooperation in stemming what at that time looked like a tide of communist aggression in Europe and Asia. These informal sessions ultimately developed into a system of prohibitions, enforced by a number of countries from the American continent, Europe, and Asia, aimed at denying strategic goods to communist nations. The legislative basis for American participation was provided by the Mutual Defense Assistance Control Act of 1951 (Battle Act). ${ }^{14}$

The interested countries have since established the International Coordinating Committee on Strategic Trade with Communist Countries (COCOM). ${ }^{15}$ The Committee maintains a list of goods which are uniformly denied to communist countries, although each government reserves to itself the right to deny export licenses to additional classes of goods. Accordingly, there are considerable discrepancies in the trade policies of the countries involved which sometimes lead to conflicts among the member countries. One example is Fruehauf Corp. v. Massardy, ${ }^{16}$ which concerned the execution of a contract between Fruehauf-France and Berliet, S.A., for the delivery of sixty vans earmarked for shipment to the People's Republic of China. In January, 1965, the U.S. Treasury Department directed Fruehauf (which was two-thirds

${ }^{12}$ Lee, U.S. Policy Toward China: From Economic Warfare to Summit Diplomacy, in ChINA's TRADE With THE West: A Political and Economic ANalysis 33 (A. Stahnke ed. 1972); 1957 U.S. Dep't of State, Mutual Defense Assistance Control Act Reports 32.

${ }^{13}$ Lee, supra note 12, at 43-44. See also Garson, The American Trade Embargo Against China, in China Trade Prospects and U.S. Policy 23-43 (A. Eckstein ed. 1971).

1422 U.S.C. \$§ $1611-13$ (1970).

15 Initially the Committee, headquartered in Paris, consisted of two subcommittees, one dealing with European communist countries, and the other with Far Eastern communist countries. In due course the two were merged into one body. See generally Lee \& McCobb, United States Trade Embargo on China, 1949-1970: Legal Status and Future Prospects, 4 N.Y.U.J. INT'L L. \& Pol. I (1971). 165 Int'l Legal Materials 476 (1966). 
on April 4, 1971, President Nixon announced further ameliorations in travel and trade restrictions: visas for visitors from China were to be expedited; U.S. currency controls were to be relaxed to permit the use of dollars in trade with the P.R.C.; American vessels and planes were to be allowed to carry Chinese cargoes between non-Chinese ports; U.S. firms were permitted to fuel Chinese ships and aircraft (except those bound to and from North Vietnam, North Korea, or Cuba); and American-owned foreign flag carriers were permitted to call at Chinese ports. ${ }^{26}$

The rationale behind these various steps was to modify the U.S. regimen of China trade regulations in accordance both with changes taking place in other countries and with changing attitudes in the United States itself. The most significant domestic factor was the armistice in South Vietnam which permitted the disengagement and withdrawal of American forces from that country. At least in part, that armistice had to be credited to China's policy of reducing tensions with the United States.

After the June 10, 1971 announcement removing the need for special export licenses for goods and commodities excluded from the list, included items could still be exported under the condition that a special license be obtained-subject only to the general provisions safeguarding American national security-in accordance with the U.S. export control regulations. Moreover, under the general license provisions all imports from China were allowed entry into the United States subject to the usual controls and customs duties relating to goods originating in communist countries. The P.R.C. was also included in the June 10, 1971 termination of the requirement that fifty per cent of wheat, flour, and other grain exports be carried in American bottoms. ${ }^{27}$ The June announcement was complemented by that of February 14, 1972, which placed the P.R.C. in country group "Y" on the Commodity Control List of the Department of Commerce, finally elevating China to the same status accorded the Soviet Union. ${ }^{28}$

\section{$\mathrm{V}$}

\section{Toward a Bilateral System}

Further progress in the development of U.S. economic cooperation with China calls for bilateral action-a formal or informal trade agreement which would meet the requirements of section 231 of the Trade Expansion Act of $1962,{ }^{29}$ and a legislative act calling for a reciprocal trade agreement to grant favorable tariff rates, a most-favored-nation clause, or duty free status. Of all the nations with a communist regime, only Yugoslavia and Poland are in this category. Nevertheless, there seem to be indications that the time may come eventually when China will also be offered a more formal arrangement regarding terms of trade. A statement of policy suggesting this development appears in the so-called "Shanghai Communique" issued at the termination

\footnotetext{
267 Weekly Compilation of Presidential Documents 628 (1971).

${ }^{27}$ See 64 DeP'T State Bull. 815 (1971).

${ }^{28} 37$ Fed. Reg. 3511 (1972). See also 66 Dep't State Bull. 291 (1972).

${ }^{29} 19$ U.S.C. $\& 1861$ (1970).
} 
of the President's visit to China in February of 1972:

Both sides view bilateral trade as another area from which mutual benefit can be derived, and agreed that economic relations based on equality and mutual benefit are in the interest of the peoples of the two countries. They agree to facilitate the progressive development of trade between their two countries. ${ }^{30}$

On the other hand, it is difficult to determine to what extent expanded trade with the United States is desired by Chinese leaders. Recent remarks by Undersecretary for Economic Affairs William J. Casey indicate that there is little hope for a rapid growth in the volume of trade between the U.S. and China, even though some progress has been made. ${ }^{31}$ Indeed, given the highly centralized trade regime presently prevailing in China, there is no reason to suppose that expansion of foreign trade will be other than a selective process. The fact that Chinese importers have not availed themselves of the credit opportunities available to them in the United States suggests a continuing reluctance to expand American trade. ${ }^{32}$ Our experience in trading with the communist countries on the whole confirms that foreign trade is primarily a part of domestic industrialization plans, used almost exclusively to expand their own productive capabilities.

\footnotetext{
3066 DeP'T State Bull. 438 (1972).

31 See 69 Dep't State Bull. 567 (1973).

${ }^{32}$ Starr, supra note 1 , at 30 .
} 